\title{
The Present Sensing Technique in Welding Process. $^{*}$
}

\author{
by Eizo Ide**, Hiroshi Fujimura*** \\ キーワード:溶接プロセス, センシング, センサ, 溶接線, ならい, イ \\ ンテリジェント，マイクロエレクトロニクス，情報処理， \\ 超音波, 自動化
}

\section{1.はじめに}

溶接の良否は直接製品の品質に影響するため，オぺ レータには高度な知識と熟練が要求されるにもかかわら ず,作業環境は典型的な $3 \mathrm{~K}$ 職場であり, 時代背景の変化 と共に人材の確保が難しくなっている。このため溶接の 自動化，口ボット化は他の分野に先がけて積極的に進め られて扝り，各方面で大きな成果が得られている。

溶接を自動化する場合，制御に必要な情報を得るため のセンサ技術が重要なことは自明のことであり，自動化 の進展はセンサ技術の開発と密接な関係にある。

最近のエレクトロニクス, 情報処理技術の発達はめざ ましく、これらの技術に支えられているセンサ技術もま た加速度的に進歩すると考えられる。

本稿では，これまでに開発され，自動溶接装置に㬰用 されて来たアーク溶接用センサ技術を主にレビューし， 続いて今後期待されるセンサ及びその機能, さらには高 密度エネルギビーム溶接（EBW，レーザ溶接）のセンシ ング技術についても述べる.

\section{2. アーク溶接用センサ}

自動溶接装置はメカニズムとエレクトロニクスが合体 したいわゆるメカトロニクシステムである。図1にシス

\footnotetext{
*原稿受付 平成 3 年 1 月 25 日

**正 員 三菱重工業(㧣) Member Mitubishi Heauy Industry

***正 員 三菱重工業獭 Member Mitubishi Heauy Industry
}

テムの5大要素を示すが1)，センサなくしてシステムは 成立しない。センサーは物理, 化学量を電気量に変換市 るデバイスであり，さまざまな原理にもとづいて作動す るが, 溶接用センサとしては次の条件を満足しなければ ならない2).

（1）溶接プロセスに対応した精度を確保できること

（2）溶接プロセスによる外乱 (光, 熱, ヒューム, ス パッタ，電磁気など）の影響を受けない

(3）十分な耐久性がある

(4) コストが安い

(5) メンテナンスが容易である

(6) コンパクト (小型, 軽量)である

（7）汎用性が大きい

次に, センサの検出目的は次の 2 つに分けられる゙.

（イ）溶接操作環境の測定, 検出

(口) 溶接過程の監視, 検查

(イ)は被溶接材の形状, 溶接線の位置とその変動, 開 先形状など, 溶接過程が進行する環境条件を事前に測定, 検出しょうとするものである。

（口）は溶接過程の進行が適正か否かを監視，検查する もので，形成されたビートの良否，欠宿発生の有無など のインプロセス検查もこの範暿に入る.

ここでは，これまでに開発されて来た1)溶接線ならい 用センサ，2) 溶接条件の制御用センサ及びセンサシステ ムについてまとめてみる.

\section{1 溶接線ならい用センサ}

センサの種類は接触式と非接触式とに大別されるが, ここではさらに作動原理で分類する. 


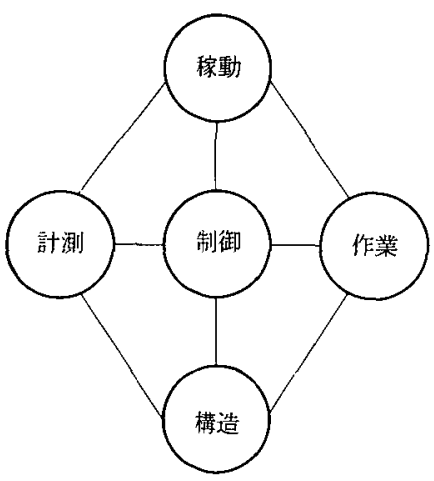

(a) 人およびメカトロニクスシステムの5大機能

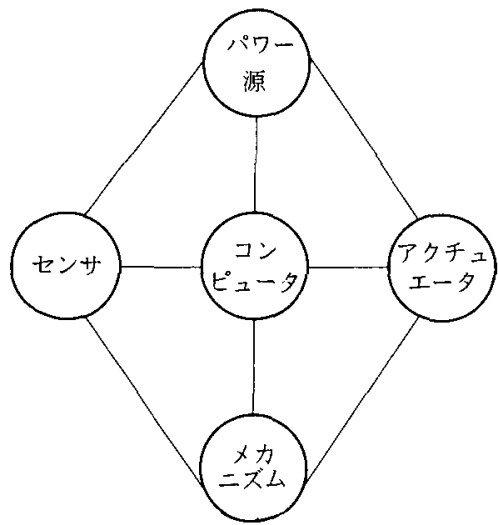

(b) メカトロニクスシステムの5大要素

图 1 人とメカトロニクスシステムの 5 大要素

\subsection{1 機械的ガイドローラ}

溶接する開先または基準となる板をがイドローラが機 械的に追従する方式で，センサとして最も単純で，早期 から用いられている。しかし，検出位置とアーク点とが 離れているために，直線状の継手が一定の曲率の継手に しか使用できないこと，ならうべき開先または板に突起 物などの障害物があれば外乱として直接誤差となるこ と, バネ,エアシリンダー，偏向車輪などローラ押付機 構の作動不良になりやすいことなどからあいまって一般 的に信頼性が低い。

図 2 及び図 3 は, サブマージアーク溶接で前者がV型 開先の直線継手へ, 後者がスミ肉溶接へ適用された例4 である。

\section{1 .2 電気信号検出接触プローブ}

ならう開先にプローブを接触させ, 開先とプローブとの 相対的な位直変化を電気信号で出力するセンサである.

このセンサには各種の検出方式占があり，ここでは 2 自 由度の電気接点式と差動トランス式を図 4, 図 5 に示す.

また，機械式ならいと同様，アーク点と位置とが離れ ているが，これを改善するために記憶遅延再生方式及び 教示再生方式と呼ばれる方法的が使用されることもある。

\section{1 .3 光学式センサ}

人間が得る情報の大部分は視覚から得ていると言われ る. 光学式センサは視覚に対応するものもありこれま でにも本センサを用いた多くの試みがなされて来た. 初期の光学式センサに，ガス切断に多用されているアイ トレーサの原理を溶接線ならいに応用したもの゙があ る、これはあらかじめ，ならう開先線と平行に白線を描 いておきこの白線上を溶接へッドに連結したアイト レーサでならうものである。(図 6) 7 )

光学式センサは, 用いる受光面光電素子の配列によっ て，(a) ポイントセンサ，(b)リニアセンサ，(c)エリ. ア (画像) センサに大別される $\left(\right.$ 図 7 ${ }^{21}$. 図 $8^{71}$ はエリア

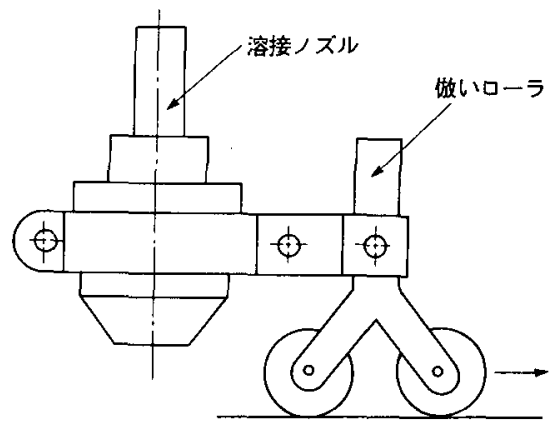

図 2 開先做い用ローラ

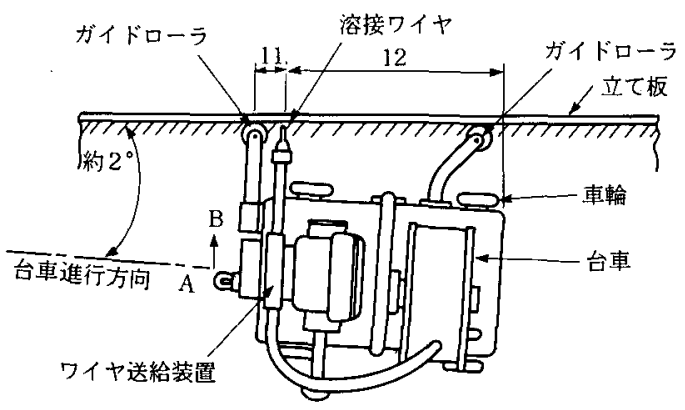

图 3 SW 101 の溶接機の例

センサを用いた光切断法による開先ならいシステムの1 例を示す。

\section{1 .4 電磁気センサ}

図 921は電磁気センサの原理で, 被検出物から検出コイ ルまでの距離 $(\mathrm{H})$ とアナログ出力電圧 $(\mathrm{V})$ とが直線関 係にあることを示す。このセンサをならい制御に適用し た例を図 $10^{2)}$ に示す。

電磁気センサを用いたシステムは実際の生産現場でも 


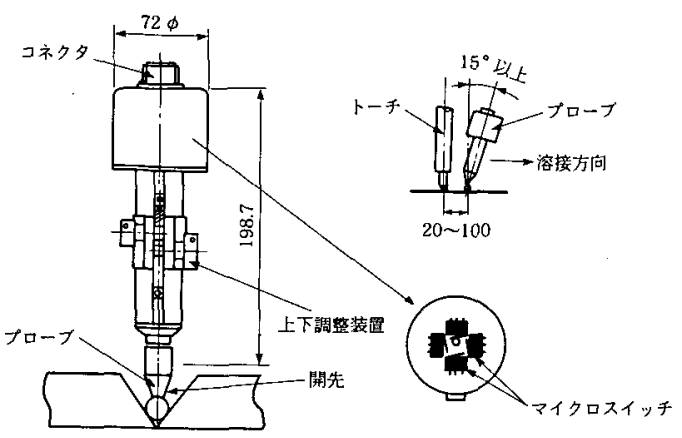

图4 電気接点内蔵接触式プローブの 1 例

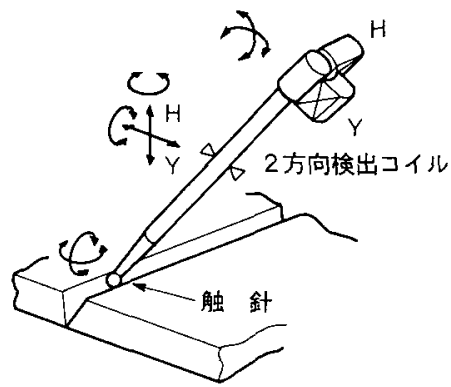

図 5 接触プロープ

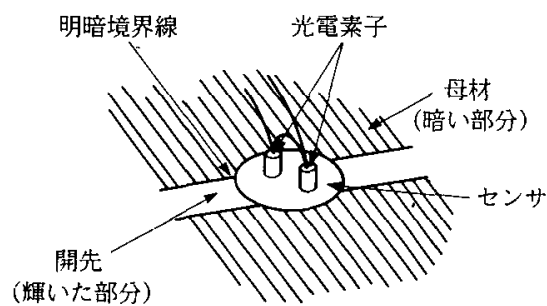

(a)

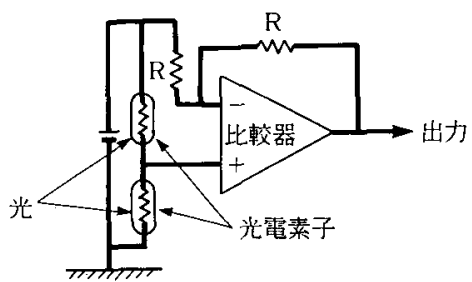

(b)

図 6 光電素子を用いる方式の例

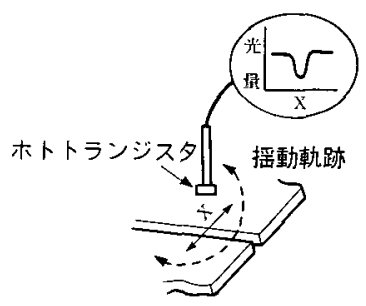

(a) ポイントセンサ
多用されている。

\subsection{5 アータ現象を利用する方法}

溶接アーク現象が変化する時, そのパラメータ（溶接 電流，アーク電圧，給電チップと被溶接物間との距離な ど）の変化を検出または演算して溶接線ならい及び溶接 条件制御に利用する方法である，本法は，1）アーク位置 と検出位置が同一である，2) 溶接へッドのまわりに特別 のセンサを装備する必要がない，3)ワイや湾曲の影響を 受けないなどの長所がある一方，オシレーションが必須 のため溶接条件が制約されるなどの欠点がある 在ロボット溶接, 自動溶接に広く利用されている.

2.1 .6 溶接ワイヤ接触式センサ

溶接を行う前に溶接の開始点や終了点を検出するため

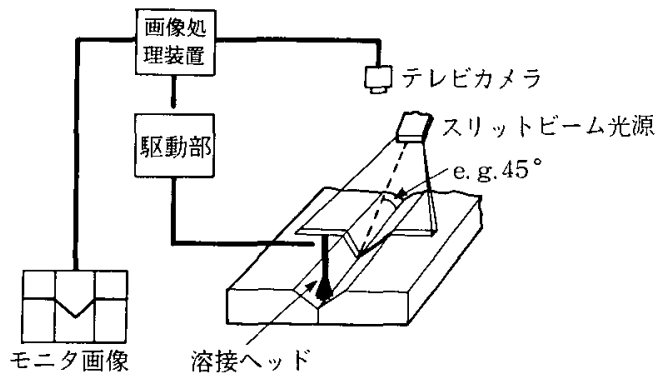

図 8 光切断方式の 1 例

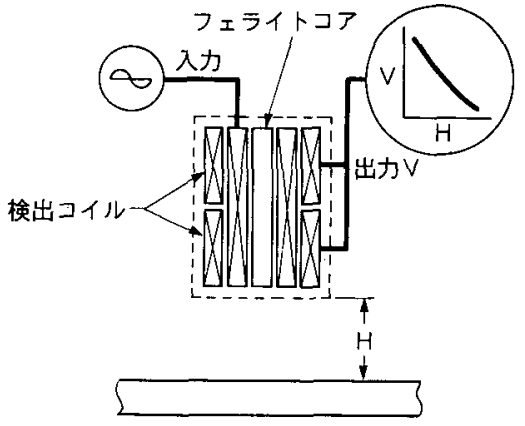

図 9 電磁気センサ

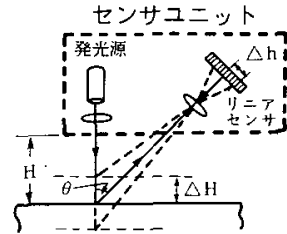

(b) リニアセンサ

図 7 光センサによるならい制衔

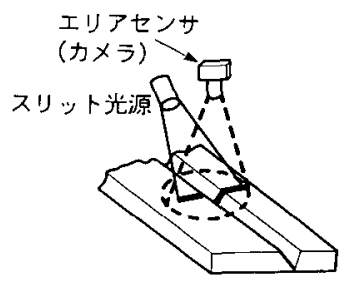

（c）エリアセンサ 


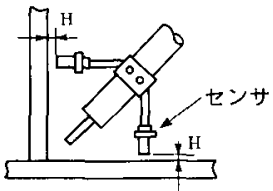

(a) すみ肉継手

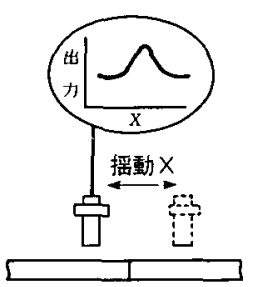

(b) 突合せ継手
のセンサで，前途の接触プローブの発展型とも考えられ るが，溶接ワイヤ(TIG 溶接ではW 電極) を用いるのが 特徵である。図 $11^{2)}$ に示すのは溶接ワイヤが開先面と接 触した時の電流または電庄の変化を検出して，あらかじ め与えられていた開先形状情報と接触位置から溶接適正 位置を割り出す方式である。

\section{1 .7 超音波センサ}

超音波センサは光学式センサと同じく非接触式である が, 最近では小型化・高精度化が達成せられている，超 音波センサは，振動子から発信された超音波が空気中を 伝わり対象物に到達した後，反射波となってセンサ部に 戻ってくるので，送信波が発振されてからセンサ部に反 射波が届く時間（t）を求めることにより，対象物とセン サ間の距離に換算するのが動作原理である，この時, 距 離は次の式で表わされる.

$$
\text { 測定距離=測定時間 }(\mathrm{t}) \times \frac{\text { 音速 }(\mathrm{v})}{2}
$$

精度を上げるために，極めて波長が短かい超音波パル スを用いており，表 1 に代表的な仕様の一例を示す。

本センサは, アーク溶接ロボットのアームに対する障 害物，溶接トーチの障害物等の検出や溶接開先に対する トーチの位置センサへの利用が考えられる。

これまでに述べた以外のシームならいセンサとして
は,シールドガスと同種のガスを用いて狭開先溶接の左 右ならいに適用した流体センザが報告されている。

\section{2 溶接条件制御センサ}

アーク溶接プロセスの調整，制御のための操作量には 次のものがある(0).

$\mathrm{A}$; 溶接電流, アーク電圧, アーク形状

; 溶接速度, ワイヤ送給速度

; シールドガス流, 駆動ガス, フラックスの供給量 : 溶接トーチの位置と姿勢

; 溶接材の位置, その傾き

;バッキング操作

$\mathrm{B}$ ；溶接接合部の溶け込み深き

; 溶融幅

; 溶融部の断面積や形状

;ビードの外観

; 応力発生状態

アーク溶接で良好な結果を得るためには上記 B など の因子を適正範囲に保つ必要がある。しかし，これら因 子にはオンライン計測が困難なものもあり，結果的には 上記 $\mathrm{A}$ などの操作項目と B の因子との相関に基づいて 操作項目をリアルタイム制御することになる.

ここでは，アーク特性を利用した溶接速度制御システ ムと光学式センサを用いて裹ビード幅を自動制卸した例 を示す。

2.2 .1 立向溶接における溶接速度制御システム

エレクトロガスアーク溶接において，溶接ヘッド（台 車）を上昇させるためにアーク特性を利用するものであ る.一定のワイヤ送給速度に対して，ワイヤ突出し長さ が変化すると溶接電流が変化するので, この電流が予め 設定した値になるように上昇モータを制御する。図 $12^{6)}$ に制御例を示军。

2.2 .2 片面溶接における裹ビート幅制御システム

片面サブマージアーク溶接で安定な襄ビートを得るの に, 溶融金属保持のために用いる水冷銅裹当金に受光素 子 (cds)を埋め込み, 裹面に到達するアーク光を検出し, 受光レベルを一定にするように溶接電流を帰還制御する 方式が開発，夷用化されている11)（図 13）

上記と同じ原理を用いた TIG片面溶接における裹 ビート幅制御も報告されている ${ }^{12)}$.

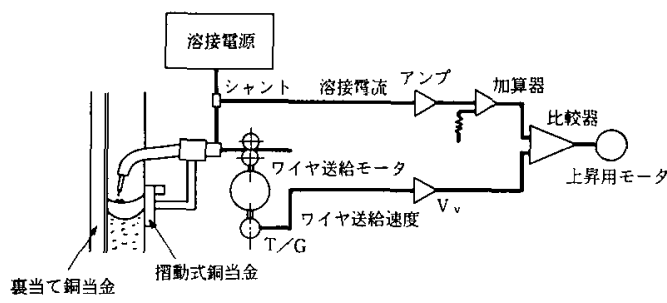

図 12 溶接速度制御の 1 例 


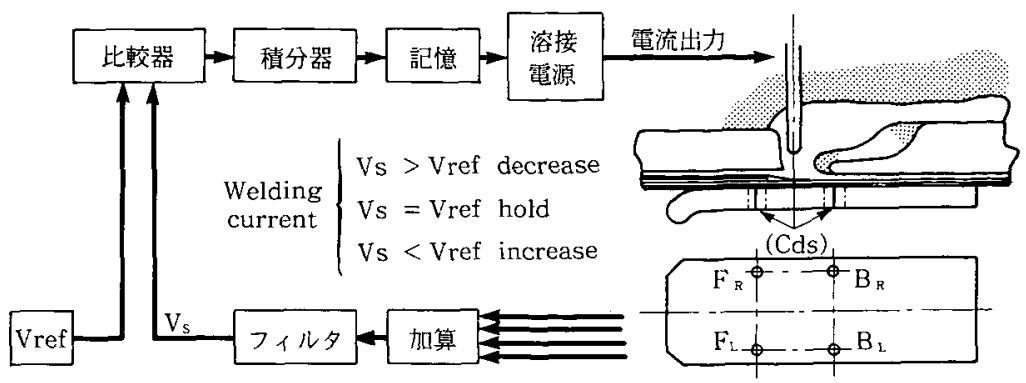

図 13 片面 SAW の裹ビート制御回路

\section{3. 新しいセンサ}

アーク溶接作業で人間が介在する割合が小さくなる程 自動溶接装置に要求される機能は多く，かつそのレベル も宮くなる．1.で述べたように，情報処理技術及びそれ に基づく制御技術が高度に発達した現在, 人間の感覚器 に相当するセンサの開発が溶接の自動化到達レベルを左 右すると考えられる。人間が外界から得る情報の大部分 は視覚によっており，自動溶接装置にとっても3次元的 視覚センサが，今後溶接アークの位置制御及び溶接プロ セス制御に大いに用いられて行くと考えられる。視覚セ ンサ技術を支える要素には，光学フィル夕系を含むカメ ラの小型化及び光学的ダイナミックレンジの拡大と共 に，検出した画像処理時間の短縮化が必要であるが，後 者はコンピュータの処理技術の向上により実用化域に達 している。ささら，最近の動问として複数のセンサから の情報を処理した後ここれらを融合して判断をするイン テリジェントセンサシステムと呼ばれているものが出現 している13). マイクロエレクトロニクスと情報処理技術 の進歩により，センサの小型化，集積化複数センサから の情報の統・融合が可能になったのが出現の理由である． 溶接アーク近傍の過酷な謤境を考慮すれば複数のセンサ が互いに短所をカバーし合って，目的とする情報を得る 上記のシステムは有効と考えられる．本システムの特徵 を具体的に述べると次のようになる。

1) 複数のセンサからの出力情報を総合的に処理して 1 つの被測定の情報を出力する一センサヒュージョンと 情報処理

2）計算機による情報処理一ソフトウェアの重要性

表 1 超音波センサの 1 例

\begin{tabular}{|c|c|}
\hline センサヘッドの大きさ & 外徍 $23 \mathrm{~mm}$ 、奥行き $25 \mathrm{~mm}$ \\
\hline 揤 定 䉓 & $50 \sim 300 \mathrm{~m}$ \\
\hline 解 能 & $0.3 \mathrm{~mm}$ \\
\hline 最小検出物体 & $0.5 \mathrm{~mm}^{\square}(100 \mathrm{~mm} に \tau)$ \\
\hline サンナ゚リング周期 & 1.5 回/秒 \\
\hline 使用周泪温 度 & $0 \sim 40^{\circ} \mathrm{C}$ \\
\hline
\end{tabular}

3） 1),2)の結果として，人間の知的行動を代行するシ ステムの実現一機械による知的操作の実現

4) 単一のセンサからの出力では決定できない被測定 量の認識をシステムで実現一情報を統合する知的活動の 実現

最近，対象システムの厳密な数式モデルがわからなく ても，オペレータの経験やシステムの特性などのあいま いな情報を処理して制御に用いるあいまい制御が各分野 で実用に供されているが溶接線のならい制御へ適用した 例がある。141

本制御法は人間の感性に近い制御ができると云われて ちり,さらに多入力, 多出力も可能であるため, センサ 本体の開発は必要であるが溶接線ならい, 溶接プロセス の監視などへの展開が今後大いに期待される。

\section{4. 高密度エネルギビーム溶接のセンシング}

現在，高密度エネルギビーム溶接として実用されてい る電子ビーム溶接, レーザビーム溶接の溶接線ならいセ ンサについて述べる。

両溶接法ともアーク溶接の千倍以上の高エネルギ密度 でシャープな溶け込みを生じるため, ビームの溶接線追 従には高精度が要求される。

\section{1 電子ビーム溶接の溶接線検出 $\left.{ }^{15}\right)$}

電子ビーム溶接は溶融幅が狭いために，正確な電子 ビーム位置制御が必要である，溶接位置検出精度及び制

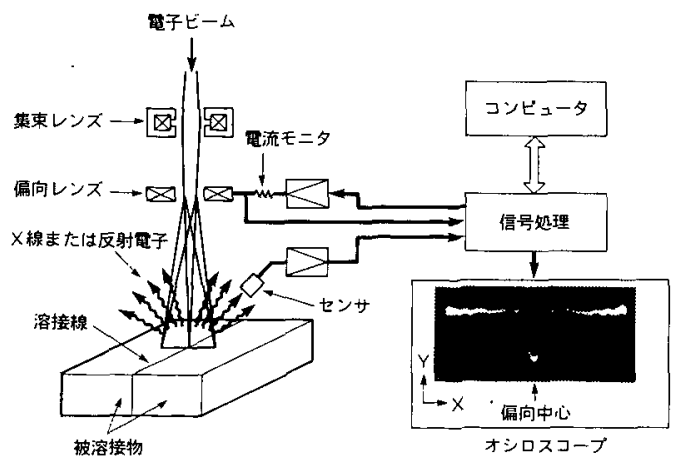

図 14 溶接線検出システム 


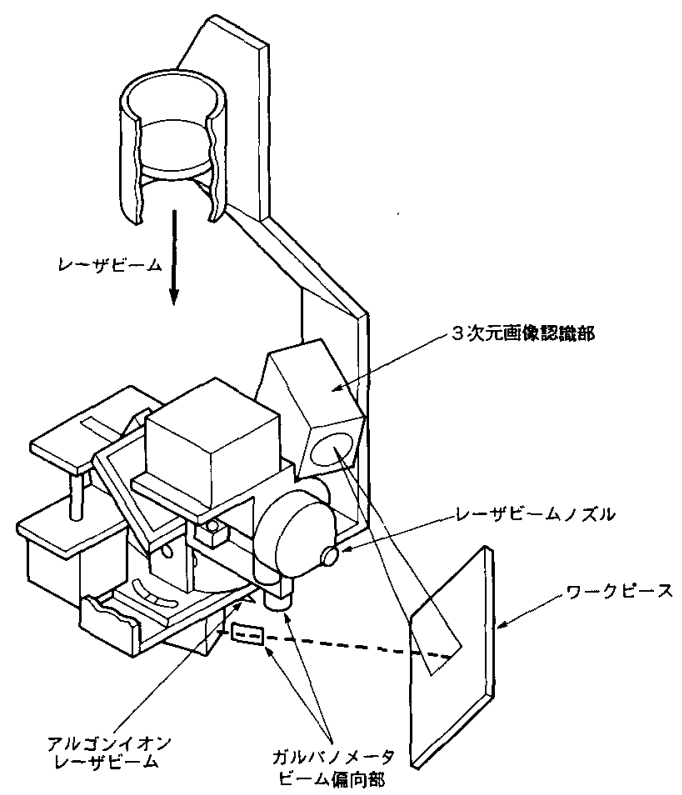

図 153 次元画像認識機能を備えた集光照射卫 ニット

御の点から, 溶接のエネルギ源である電子ビーム自身を 溶接位置の険出プローブに用いる次の方法がある。溶接 物の表面を微小電子ビームで偏向走查し, 発生するX 線 や反射電子の信号を CRT の画面に表示して,リサジュ・

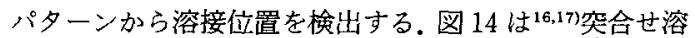
接の場合, ビームの偏向量が零の位置にマーカが表示さ れており，〈ぼみの位置とマーカ位置とが一致するよう に溶接物の位置を合わせると，ビームは溶接線を正確に 照射する。

\section{2 レーザ溶接の溶接線検出 ${ }^{15}$}

レーザ溶接に用いるビームのスポット径は通常 $1 \mathrm{~mm}$ 以下であり, シーム溶接線には高精度位置合わせをして ビームを照射する必要がある。図 $15^{18)}$ は 3 次元視覚認識

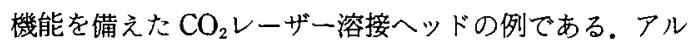
ゴンイオンレーザビームを 2 軸ガルバノメータでワータ ピース上にラスタスキャン照射する。この煇点軌跡をせ ンサから画像信号として取り込み 3 次元画像処理を行

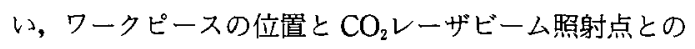
相対位置を求める.この3 次元視覚認識システムを自動 的溶接位置决めシステムに組み込み, シーム溶接線に 沿った実時間トラッキングなどを行うことが可能である。

\section{5. あとがき}

熟練した溶接士は溶接状況を目と耳で判断している が，一般に“視力が衰えると溶接の腕が急に落ちる”と 云われているように目からの情報が大半を占めているこ とは明らかである、目に相当するセンサは光学式センサ であるが，人間の視覚は三次元的なパターン認識力に優
れるだけでなく，溶融池周辺の“溶けぐあい”とか“ス ラグの流れ方”と云った動的な要因をも重要な情報とし て取り込んでおり，同等の機能を視覚センサシステムと して完成させることが望まれる。

また，人間は視覚・聴覚から得られる情報と前もって 把握しておいたマクロ的情報とを照らし合い総合的に判 断しているわけであるが，センサとしては CAD・CAM 情報, 電流電圧変化, 溶接部近傍の温度分布など, 人間 の感知し得ない情報もリアルタイムで入手できるわけ で，3.で述ベたファジー制御やニューロコンピュータな ど多元情報処理に適した手法を活用すれば，人間と同等 あるいはそれを越えるセンサの実現も可能ではなかるうか.

\section{参考文 献}

1) メカトロニクスシリーズ入閒編メカトロニクス入 門；日本機械学会編，技報堂出版

2) アーク溶接におけるセンジングと制御；溶接学 会, 溶接法研究委員会編, 第 1 編 総論

3) 井上：アーク溶接ロボット用センサー; 本誌 51 9 (1982), 735-741

4) S. B. Joness; Mechanical Approaches to Seam Tracking for Arc Welding, T. W. I. Research Rep.

5) 野村；アーク溶接用センサ及びセンサシステム, 溶接技術, $1985-7,39-43$

6) 益本ら：我が国におけるアーク溶接用センサ及び センサシステムの現状一, 本誌 52-9 (1983), $339-347$

7) 野村；アーク溶接用センサ及びセンサシステム, 溶接技術，1985-9, 65-69

8）野村；アーク溶接用センサ及びセンサシステム, 溶接技術, 1985-8,79-83

9）过ら; 狭開先ミグ溶接機の自動ならい装置, 日立 造船技報, 41 巻 2 号 (1980)

10)荒田ら：アーク溶接の自動制御一, 本誌 $41-6$ (1972), 613-648

11) NOMURA et al; Penetration Control in One Side Submerged Arc Welding, IIW Doc. XII$\mathrm{K}-99-79$

12）野村ら；ステンレス銅管のTIG片面溶接におけ る裏ビード自動制御，第 64 回溶接アーク物理委， 昭和 56 年 7 月

13）大場：インテリジェント・センサ技術, オーム社

14）アーク溶接におけるセンシングと制御；溶接学 会, 溶接法研究委員会編, 第 II編 各論

15）溶接·接合便覧；溶接学会編，丸善株式会社出版， 1990

16) G. Sayegh, et al; Automatic Alignment of E. B. on Joints Application of Welding Tube to tube Sheet in Heat Exchangers, Proc. Int Conf. on Welding Research in the 1980's, A (8) (1980) 43.

17）安永ら；電子ビーム溶接における溶接線検出法の 研究, 溶接学会論文集, 3-1 (1985), 16

18) G. T. Forrest; Closed-loop Robotic Laser Welder for the NAVY, Laser Forcus, 23-4 (1987), 158 